\title{
POLITIK HUKUM FASILITAS KEIMIGRASIAN BAGI TENAGA KERJA ASING DENGAN HUKUM KETENAGAKERJAAN INDONESIA
}

\author{
Meiliana Wanda Agesa \\ Email: meiliana20@ymail.com \\ Mahasiswa Program Magister Ilmu Hukum Program Pascasarjana \\ Fakultas Hukum Universitas Sebelas Maret Surakarta \\ Lego Karjoko \\ Email: Lkarjoko36@yahoo.com \\ Isharyanto \\ Email: masis_uns@yahoo.com \\ Dosen Fakultas Hukum Universitas Sebelas Maret Surakarta
}

\begin{abstract}
This study examines the legal politics of immigration facilities for foreign workers with Indonesian labor law. The Politics of Immigration Law should be based on a Selective Policy that benefits the Indonesian economy. There is still a conflict of norm between immigration regulations and labor regulations. This research is a prescriptive legal research with the approach of law and conceptual approach. Technique of collecting legal material of literature study and technique of analysis of law material of deduction method. This study concludes that there is disharmonization between the rules of immigration law and the labor law regulation concerning the use of foreign workers in Indonesia where, which is more inclined to provide convenience for foreign workers. This study recommends that the government make changes to the regulations on the use of foreign workers so as to create harmonization between the rules of immigration law and labor law.
\end{abstract}

Keywords: legal Politic, immigration, foreign worker and manpower

\begin{abstract}
Abstrak
Penelitian ini mengkaji politik hukum fasilitas keimigrasian bagi tenaga kerja asing dengan hukum ketenagakerjaan Indonesia. Politik Hukum Keimigrasian harus berdasarkan kebijakan selektif (Selective Policy) yang memberikan manfaat bagi perekonomian Indonesia. Masih adanya conflict of norm antara peraturan keimigrasian dengan peraturan ketenagakerjaan. Penelitian ini merupakan penelitian hukum yang bersifat preskiptif dengan pendekatan undang-undang dan pendekatan konseptual. Teknik pengumpulan bahan hukum studi pustaka dan teknik analisis bahan hukum metode deduksi. Penelitian ini menyimpulkan, adanya disharmonisasi antara peraturan hukum keimigrasian dengan peraturan hukum ketenagakerjaan
\end{abstract}


mengenai penggunaan tenaga kerja asing di Indonesia dimana, yang lebih condong memberikan kemudahan bagi tenaga kerja asing. Penelitian ini merekomendasikan agar pemerintah melakukan perubahan peraturan tentang penggunaan tenaga kerja asing sehingga tercipta harmonisasi antara peraturan hukum keimigrasian dengan hukum ketenagakerjaan.

Kata Kunci : Politik Hukum, Keimigrasian, tenaga kerja asing dan ketenagakerjaan.

\section{A. Pendahuluan}

Ketentuan dalam Pasal 27 ayat (2) UUD 1945 yang berbunyi, "tiap-tiap warga Negara berhak atas pekerjaan dan penghidupan yang layak bagi kemanusiaan." Sehingga, Negara berkewajiban untuk kesejahteraan warga negaranya, dalam hal berarti pekerjaan yang layak untuk warga Negara Indonesia harus terpenuhi. Di Era globalisasi ini, pentingnya akan kebutuhan tenaga ahli di Indonesia yang profesional membuat perusahaan-perusahaan, baik itu swasta asing maupun swasta nasional menggunakan tenaga kerja asing. Dalam bidang ketenagakerjaan yang sesuai ketentuan UUD 1945 disebutkan dalam Pasal 28D ayat (2) UUD 1945 yang mana berimplikasi pada kewajiban Negara untuk memfasilitasi warga Negara agar dapat memperoleh pekerjaan yang layak bagi kemanusiaan ( I Wayan Gde Wiryawan, 2013 : 142)

Pasal 28 ayat (2) UUD 1945 menegaskan bahwa, "setiap orang berhak untuk bekerja serta mendapat imbalan serta perlakuan yang adil dan layak dalam hubungan kerja", sehingga pengaturan tersebut sebagai landasan terhadap penggunaan Tenaga Kerja Asing (TKA) di Indonesia terhadap kondisi pasar kerja dalam negeri, kebutuhan investasi, kesepakatan Internasional dan liberalisasi pasar bebas dengan berkaitan kepentingan nasional untuk memberikan perlindungan terhadap kesempatan tenaga kerja Indonesia (TKI).

Indonesia mulai beradaptasi dalam berbagai bidang, salah satunya adalah bidang tenaga kerja dengan berlakunya Mayarakat Ekonomi Asean (MEA) tenaga kerja asing dapat lebih mudah untuk masuk pasar Indonesia. Karena dengan MEA diyakini membawa sejumlah manfaat bagi masyarakat dan Indonesia, sehingga, 
memiliki daya saing di antara kawasan Negara-negara ASEAN. MEA dibentuk dengan tujuan untuk mewujudkan integrasi ekonomi di kawasan agar tercipta tingkat pembangunan dan pertumbuhan ekonomi.

Penggunaan TKA secara filosofis yaitu asas manfaat, aspek keamanan, aspek legalitas, yaitu masuknya TKA harus mendapatkan ijin kerja dari Menteri Tenaga Kerja, sejalan dengan penggunaan TKA adalah untuk memenuhi kebutuhan tenaga kerja yang profesional di bidang tertentu yang belum dapat terisi oleh TKI dengan percepatan ahli teknologi dan peningkatan investasi. Sehingga TKA di Indonesia tidak dapat dihindari penggunaannya, dan pada prinsipnya penggunaan TKA di Indonesia adalah mereka yang dibutuhkan dalam dua hal yakni mereka TKA yang membawa modal (sebagai investor) dan membawa skill dalam hal transfer of knowledge. Selain kedua hal tersebut maka pada hakekatnya tidak di perkenankan dan harus mengutamakan penggunaan tenaga kerja dari Indonesia (C. Sumarprihatiningrum, $2006: 56)$.

Pengaturan mengenai TKA diatur dalam Undang - Undang Nomor 13 Tahun 2003 diatur pada Bab VIII tentang penggunaan TKA. Kemudian dalam rangka tertib administrasi dan kelancaran pelayanan kepada orang asing yang berkepastian hukum terhadap pemberian Izin Tinggal Keimigrasian sebagai Tenaga Kerja Asing dipandang sangat penting bagi peran pihak Imigrasi. Tujuan penggunaan tenaga kerja asing tersebut adalah untuk memenuhi kebutuhan tenaga kerja terampil dan professional dibidang tertentu yang belum dapat diisi oleh tenaga kerja Indonesia (TKI) serta mempercepat proses pembangunan nasional dengan jalan mempercepat alih ilmu pengetahuan dan tehnologi dan meningkatkan investasi asing sebagai penunjang pembangunan di Indonesia walaupun pada kenyataannya perusahaanperusahaan yang ada di Indonesia baik itu perusahaan-perusahaan swasta asing ataupun swasta nasional wajib menggunakan tenaga ahli bangsa Indonesia sendiri. Didalam melaksanakan penempatan tenaga-tenaga asing itu Pemerintah berpendapat bahwa khusus untuk menghilangkan unsur- unsur kolonial dalam struktur ekonomi 
negara kita dalam lapangan usaha yang vital bagi perekonomian nasional (H. R. Abdussalam, 2008 : 322).

Berdasarkan kebijakan Selektif (Selective Policy) yang dijabarkan pada paragaf ke VIII penjelasan Undang-Undang Nomor 6 Tahun 2011 Tentang Keimigrasian yang menyebutkan bahwa, "hanya Orang Asing yang memberikan manfaat serta tidak membahayakan keamanan dan ketertiban umum diperbolehkan masuk dan berada di wilayah Indonesia.“ (Warhan Wirasto, 2016 : 172)

Orang asing dapat dengan mudah masuk ke negeri ini salah satunya adalah adanya pemberlakuan kebijakan bebas visa kunjungan yang diberlakukan sejak pertengahan tahun 2015 silam. Dikeluarkan nya Peraturan Presiden (Perpers) Nomor 21 Tahun 2016 tentang Bebas Visa Kunjungan, yang memberikan bebas visa kunjungan bagi 169 negara. Adanya kebijakan bebas visa oleh pemerintah ini sebenarnya dengan tujuan dapat meningkatkan jumlah kunjungan wisatawan asing Indonesia. Namun, fakta di lapangan banyak warga negara asing (WNA) yang memanfaatkan visa wisata untuk bekerja. Meningkatnya jumlah Tenaga Kerja Asing di Indonesia khususnya dari Negara Cina dengan jumlah sangat besar karena semakin terbukanya negeri ini bagi lalu-lintas orang dari negara-negara lain. Jumlah tenaga kerja asing yang berada di Indonesia hingga November 2016 mencapai 74.183 pekerja meningkat 7,5 persen.

Adanya prosedur pengawasan yang ketat dan selektif mulai dalam pemberian Visa (VITAS/Visa Tinggal Terbatas) pada perwakilan Republik Indonesia di luar negeri, kegiatan yang dilakukan hingga orang asing meninggalkan wilayah Indonesia maka diharapkan akan memberikan saringan dan pengawasan yang efektif terhadap orang asing, sesuai dengan sistem hukum yang berlaku di Indonesia dahulu (Hendra Karianga, 2011: 88).

Pemberlakuan bebas visa kunjungan ini dikhawatirkan membawa dampak negatif berupa menyusupnya para pekerja asing secara ilegal ke Indonesia terutama berasal dari Cina Pada saat yang sama, kebijakan bebas visa ini dapat pula menjadi 
celah bagi masuknya para teroris, pengedar narkoba dan para pelaku kejahatan lainnya.

Terbukanya pintu dengan memberikan fasilitas terhadap TKA yang akan bekerja di Indonesia, maka diharapkan penggunaan TKA pada perusahaan di Indonesia dapat tepat guna sesuai dengan kompetensi yang diperlukan. Sehingga kedatangan TKA diharapkan dapat ikut berpartisipasi dalam pembangunan nasional. Hal ini sejalan dengan pembukaan Undang-Undang Dasar Negara Republik Indonesia 1945 pada paragraf ke IV, yang mengatakan bahwa "dan untuk memajukan kesejahteraan umum, dan mencerdaskan kehidupan bangsa, "Kegiatan pengawasan sangat diperlukan terutama untuk mengamati, mendeteksi, mencegah, dan menindak apabila ada orang asing tersebut melakukan pelanggaran melakukan kegiatan yang tidak sesuai dengan izin tinggal yang diberikan kepadanya selama berada di wilayah Indonesia.

Untuk mewujudkan dan mempercepat alih ilmu pengetahuan dan tehnologi tenaga kerja asing dengan tenaga dalam negeri di Indonesia, maka penggunaan TKA harus sesuai tujuan Negara dalam pembangunan nasional dan berdasarkan aspek hukum keimigrasian dan hukum ketenagakerjaan juga peraturan perundanganundangan yang berkaitan dengan TKA di Indonesia. Bertitik tolak dari pokok-pokok pemikiran tersebut, maka penelitian ini akan mengkaji mengenai politik hukum fasilitas keimigrasian bagi tenaga kerja asing dengan hukum ketenagakerjaan Indonesia.

\section{B. Metode Penelitian}

Penelitian ini adalah penelitian hukum doktrinal yang menggunakan metode studi kepustakaan. Bahan hukum yang digunakan adalah bahan hukum primer yang meliputi peraturan perundang-undangan mulai dari Undang-Undang Dasar Negara Republik Indonesia Tahun 1945, Undang-Undang, dan peraturan perundangundangan lainnya yang terkait dengan masalah penelitian. Sumber informasi hukum 
mencakup juga bahan hukum sekunder seperti buku-buku referensi, majalah hukum atau jurnal hukum, surat kabar, dan hasil karya ilmiah yang relevan dengan topik penelitian (Peter Mahmud Marzuki, 2014: 237-240).

\section{Hasil Penelitian dan Pembahasan}

Pergeseran arah politik hukum keimigrasian Indonesia dari Undang-Undang Nomor 9 tahun 1992 ke Undang-Undang Nomor 06 Tahun 2011. Di satu sisi, perkembangan globalisasi menyebabkan arah politik hukum keimigrasian dalam Undang-Undang Nomor 06 Tahun 2011 lebih memberikan kemudahan pergerakan orang asing untuk masuk dengan mengedepankan aspek pelayanan. Namun demikian, di sisi lain, arah politik hukum Undang-Undang ini juga memperketat aspek pengawasan orang asing, dengan lebih mengedepankan aspek pengawasan represif, terutama dengan penegakan hukum pidana keimigrisian. Hal-hal tersebut diarahkan dengan tetap sejalan dengan nilai-nilai dan norma-norma HAM yang diakui secara universal.

Undang-Undang Nomor 06 Tahun 2011 juga diarahkan untuk menjawab perubahan sistem kewarganegaraan Republik Indonesia berdasarkan Undang-Undang Nomor 12 Tahun 2006 tentang Kewarganegaraan Republik Indonesia berkaitan dengan pelaksanaan Fungsi Keimigrasian, antara lain mengenai berkewarganegaraan ganda terbatas dan pewarganegaraan melalui pernyataan karena perkawinan campuran baik bagi laki-laki maupun perempuan asing yang kawin dengan WNI (Susi Dwi Harijanti, 2007:127).

Perkembangan dari segi substansi hukum keimigrasian, ada beberapa perkembangan prinsip politik hukum keimigrasian dari Undang-Undang Nomor 9 tahun 1992 ke Undang-Undang Nomor 06 Tahun 2011. Kedua undang-undang menganut prinsip selective policy dalam hal masuk dan keluarnya orang dari dan ke wilayah Indonesia didasarkan pada aspek manfaat terhadap kepentingan nasional. Undang-Undang Nomor 9 tahun 1992 lebih dilekatkan pada prinsip keamanan 
nasional, sementara dalam Undang-Undang Nomor 06 Tahun 2011 prinsip tersebut dilekatkan dengan prinsip hak asasi manusia. Hal tersebut menunjukkan bahwa pembentuk Undang-Undang Nomor 06 Tahun 2011 menginginkan adanya keseimbangan antara prinsip kebijakan selektif dengan prinsip HAM. Selain penghapusan penangkalan terhadap WNI, Termasuk dalam beberapa hal mengkoreksi atau mengatur kembali berbagai ketentuan yang sebelumnya belum sejalan atau belum mengakomodasi dengan nilai-nilai HAM pada umumnya, misalnya dalam hal hak atas pekerjaan bagi orang asing tertentu yang berada di Indonesia. Prinsip kebijakan selektif berdasarkan Undang-Undang Nomor 06 Tahun 2011. dalam hal tertentu lebih ketat dibandingkan dalam Undang-Undang Nomor 9 tahun 1992, terutama dalam hal prosedur masuk dan keluarnya orang dari wilayah Indonesia maupun keberadaan orang asing di Indonesia (Tony Mirwanto, 2016 : 54).

Presiden mengeluarkan kebijakan bebas visa ini adalah untuk meningkatkan devisa melalui pariwisata. Namun, di khawatirkan adanya dampak negatif seperti, dari sisi keamanan yang berpotensi timbul karena bebas visa kunjungan. Kebijakan bebas visa kunjungan yang dituangkan dalam Peraturan Presiden Nomor 21 Tahun 2016 tentang Bebas Visa Kunjungan berdampak negatif di sejumlah daerah. Pelanggaran yang dilakukan warga negara asing (WNA) terkait kebijakan bebas visa kunjungan adalah administrasi imigrasi, yaitu penyalahgunaan izin tinggal yang hanya maksimal 30 hari, namun banyak disalahgunakan untuk bekerja.

Peraturan Presiden Nomor 21 Tahun 2016 mengamanatkan bahwa Penerima Bebas Visa Kunjungan diberikan izin tinggal kunjungan untuk 30 hari dan tidak dapat diperpanjang masa berlakunya ataupun dialih statuskan menjadi izin tinggal lainnya. Penerima Bebas Visa Kunjungan pun dapat keluar dan masuk melalui 124 Tempat Pemeriksaan Imigrasi darat, laut dan udara. Orang Asing penerima Bebas Visa Kunjungan dapat melakukan kegiatan untuk tujuan wisata, kunjungan keluarga, sosial, seni dan budaya, tugas pemerintahan, memberikan ceramah atau mengikuti seminar, mengikuti pameran internasional, mengikuti rapat yang diadakan dengan

Jurnal Hukum Dan Pembangunan Ekonomi (Vol.6 No.2) 61 
kantor pusat atau perwakilan di Indonesia, dan untuk meneruskan perjalanan ke luar negeri. Apabila izin tinggal untuk tujuan kunjungan selama 30 hari yang diakomodir melalui Bebas Visa Kunjungan dirasa tidak memadai, fasilitas Visa Kunjungan saat Kedatangan (Visa on Arrival) maupun Visa Kunjungan masih dapat digunakan. Adanya Fasilitas ini diharapkan dapat memberikan manfaat yang lebih dalam peningkatan perekonomian Indonesia dengan peningkatan jumlah kunjungan wisatawan mancanegara.

Orang asing yang ingin bekerja di Indonesia harus memiliki sponsor dari perusahaan yang akan ditempati untuk bekerja, dikatakan sebagai tenaga kerja asing sesuai dengan Undang-undang Nomor 13 tahun 2003 tentang Ketenagakerjaan, menyatakan bahwa : Tenaga kerja asing adalah warga negara asing pemegang visa dengan maksud bekerja di wilayah Indonesia”. Tenaga Kerja Asing ("TKA”) yang dipekerjakan oleh pemberi kerja wajib memenuhi persyaratan, antara lain yaitu memiliki pendidikan yang sesuai dengan syarat jabatan yang akan diduduki oleh TKA dan memiliki sertifikat kompetensi atau memiliki pengalaman kerja sesuai dengan jabatan yang akan diduduki TKA paling kurang 5 (lima) tahun. Pemberi Kerja TKA sebelumnya harus memiliki Rencana Penggunaan Tenaga Kerja Asing (RPTKA) dan Izin Mempekerjakan Tenaga Kerja Asing (IMTA).

Tujuan dikeluarkannya peraturan Presiden nomor 69 tahun 2015 kepada 45 negara mengenai bebas visa kunjungan, diharapkan untuk dapat memberikan dampak positif bagi Negara kita dengan semakin dikenal nya Indonesia di kanca dunia Internasional melalui pariwisata Indonesia, dan meningkatkan devisa bagi Negara. Hal tersebut dapat terlaksana apabila pemerintah dan pihak kemigrasian bekerja sama dalam melakukan seleksi serta pengawasan terhadap orang asing yang masuk ke Indonesia bersama dalam peran aparatur keamanan Negara dan masyarakat. Karena hanya orang asing yang memberikan manfaat dan perekonomian bagi Indonesia yang dapat masuk dan dan berada di Indonesia melalui bebas visa kunjungan. 
Persyaratan terhadap Tenaga Kerja Asing yang harus bisa berbahasa Indonesia sebelumnya di atur dalam Pasal 26 ayat 1 huruf d Peraturan Menteri Tenaga Kerja dan Transmigrasi (Permenakertrans) Nomor 12 Tahun 2013, tetapi syarat tersebut sudah di hilangkan kemudian mengalami perubahan menjadi Permenaker Nomor 16 Tahun 2015 dan diubah lagi menjadi Permenaker 35 Tahun 2015 tentang perubahan atas Permenaker Nomor 16 Tahun 2015 tentang Tata Cara Penggunaan Tenaga Kerja Asing. Perubahan tersebut, justru dapat melonggarkan penggunaan TKA, salah satunya dilihat dari penghapusan mengenai syarat dapat berkomunikasi dalam bahasa Indonesia.

Berbeda dengan Provinsi Jawa Tengah yang berdasarkan peraturan perundangundangan yang berlaku yaitu Permenaker Nomor 16 Tahun 2015 tentang Tata Cara Penggunaan Tenaga Kerja Asing. Dalam Permenaker tersebut syarat kemampuan berbahasa Indonesia yang dibuktikan dengan kepemilikan sertifikat berbahasa Indonesia telah dihilangkan, namun melalui Surat Edaran Gubernur Jawa Tengah Nomor 560/ 016667 Tanggal 23 Oktober mengisyaratkan bahwa per tanggal 1 Januari 2016 setiap tenaga kerja asing yang akan bekerja di wilayah Provinsi Jawa Tengah wajib memiliki sertifikat berbahasa Indonesia. Hal tersebut dimaksudkan agar pada saat terjadi alih kemampuan dan alih teknologi tidak terjadi ketimpangan (miss communication).

Sebelum adanya Permenaker yang menyatakan bahwa TKA wajib menguasai bahasa Indonesia dan di hapuskan pada waktu itu, alasan pemerintah dalam ketentuan Pasal 26 ayat 1 huruf d Permenakertrans Nomor 12 Tahun 2013 adalah :

a Asas resiprokalitas, misalnya jika kita mengirim tenaga kerja ke Korea kita latih bahasa Korea, jika ke Jepang dilatih bahasa Jepang.

b Bagian kebijakan pengendalian TKA, menyangkut kualifikasi TKA tersebut. 
c Kemahiran berbahasa Indonesia karena TKA harus memahami kultur dan budaya Indonesia, memahami aturan ketenagakerjaan di Indonesia.

Peraturan Menakertrans Nomor 12 tahun 2013 pada waktu itu belum dapat diterapkan secara efektif, karena belum adanya petunjuk teknis tentang pelaksanaan dan pengawasan TKA berbahasa Indonesia tersebut. Namun sebelum Kementerian Ketenagakerjaan dapat menyelesaikan petunjuk teknis pelaksanaan Permenakertrans Nomor 12 tahun 2013 tersebut, persyaratan TKA mampu berbahasa Indonesia tersebut telah dihapus atas perintah Presiden dengan maksud penghapusan syarat berbahasa Indonesia tersebut harus dilakukan untuk memperlancar investasi asing di Indonesia.

Penghapusan salah satu syarat bagi TKA tersebut yang bekerja di Indonesia semakin memberi kemudahan masuknya TKA ke Indonesia, dengan adanya TKA yang bekerja di Indonesia sebagian (besar) kemungkinan tak mampu berkomunikasi dalam bahasa Indonesia dengan baik. Seperti, tahun 2015 lalu kasus pemberitaan peresmian PLTU Celukan Bawang di Buleleng Bali, memberitakan peresmian PLTU Celukan Bawang menggunakan bahasa Mandarin, tenaga kerja yang hadir pada acara tersebut semua TKA asal Tiongkok, hanya pejabat Pemerintah Daerah setempat yang memberi sambutan menggunakan dalam bahasa Indonesia.

Ketentuan dalam Pasal 33 Undang-Undang Nomor 24 Tahun 2009 tentang Bendera, Bahasa, dan Lambang Negara serta Lagu Kebangsaan yaitu :

(1) Bahasa Indonesia wajib digunakan dalam komunikasi resmi di lingkungan kerja pemerintah dan swasta.

(2) Pegawai di lingkungan kerja lembaga pemerintah dan swasta sebagaimana dimaksud pada ayat (1) yang belum mampu berbahasa Indonesia wajib mengikuti atau diikutsertakan dalam pembelajaran untuk meraih kemampuan berbahasa Indonesia. 
Kemampuan wajib berbahasa Indonesia bagi TKA sebagai bentuk pengendalian Tenaga Kerja Asing (TKA),didukung dalam ketentuan Undang - Undang Nomor 24 Tahun 2009. Ketidaksesuaian dalam produk hukum yang mengatur persyaratan TKA dalam bekerja terhadap Permenaker Nomor 16 Tahun 2015. Penggunaan TKA dalam Undang-Undang Nomor 13 Tahun 2003 yang menjadi poin penting adalah TKA dapat bekerja di Indonesia dengan catatan melakukan transfer ilmu pengetahuan kepada tenaga kerja lokal. Sehingga sudah seharusnya dapat berkomunikasi yang baik dan wajib berbahasa Indonesia adalah penting.

Kewajiban bagi TKA untuk bisa menguasai bahasa Indonesia, sampai saat ini hanya di terapkan di Provinsi Jawa Tengah mealalui surat edaran gubernur. Surat edaran adalah naskah dinas yang memuat petunjuk tentang hal-hal yang harus diperhatikan dan dilakukan berdasarkan peraturan/ketentuan yang ada. Surat edaran bersifat umum dan berlaku tetap. Meskipun di wajib bahasa Indonesia di Jawa Tengah hanya berdasarkan Surat Edaran, tetapi setidaknya sudah ada suatu hal yang dapat dilakukan dan di terapkan, bertujuan untuk tidak memberi kelonggaran bagi TKA.

Ada empat prinsip pengendalian penggunaan TKA di Indonesia, berdasarkan dari kesimpulan dalam Undang-Undang Nomor 13 Tahun 2003 tentang Ketenagakerjaan yaitu:

1. Pertama adalah setiap pemberi kerja yang mempekerjakan TKA harus memiliki ijin dari menteri atau pejabat yang ditunjuk. Ijin yang dimaksud adalah Ijin Mempekerjakan Tenaga Kerja Asing (IMTA). Untuk mendapatkan IMTA, sponsor atau pemberi kerja terlebih dahulu harus mengajukan permohonan pengesahan Rencana Penggunaan Tenaga Kerja Asing (RPTKA). Untuk mendapatkan pengesahan RPTKA, pemohon harus mengisi formulir secara lengkap berupa, isian identitas pemberi kerja, jabatan yang akan diduduki TKA, jumlah TKA yang akan dipekerjakan, besaran upah yang dibayarkan kepada TKA, uraian jabatan dan syarat jabatan yang diduduki 
TKA, jangka waktu penggunaan TKA, lokasi kerja TKA, penunjukan TKI pendamping, dan rencana pendidikan dan latihan yang akan diberikan kepada TKI pendamping.

2. Prinsip Kedua adalah Sponshorship dimana pemberi kerja orang perorangan dilarang mempekerjakan TKA. Pemberi kerja kepada TKA harus berbadan hukum. Dalam pengajuan RPTKA, selain mengisi formulir, pemberi kerja juga wajib menunjukkan surat ijin usaha dari instansi yang berwenang, akta dan keputusan pengesahan pendirian atau perubahan yang telah disahkan oleh instansi yang berwenang, bagan struktur organisasi, keterangan domisili kegiatan perusahaan dari pemerintah setempat, NPWP pemberi kerja TKA.

3. Selektif dimana TKA dipekerjakan dalam hubungan kerja dalam jabatan tertentu dan waktu tertentu. Sebelum permohonan RPTKA disahkan Direktur Pengendalian Penggunaan Tenaga Kerja Asing Kementerian Ketenagakerjaan wajib melakukan penilaian kelayakan permohonan RPTKA. Ini dilakukan dalam rangka untuk melindungi kesempatan kerja bagi tenaga kerja Indonesia. Jabatan-jabatan dalam perkerjaan yang dapat dan tidak dapat diduduki oleh TKA juga sudah diatur dalam beberapa Keputusan Menteri. Jika ada jabatan baru yang merupakan konsekuensi dari adanya perkembangan teknologi dan jabatan ini belum diatur dalam peraturan menteri dapat atau tidaknya untuk diduduki oleh TKA maka diperlukan pertimbangan teknis dari instansi terkait ( Ujang Charda S., $2014: 138$ ).

4. Keempat, Security Penggunaan TKA harus sesuai dengan peraturan perundangan yang berlaku di Indonesia dan menyangkut berbagai asas agar keberadaan TKA tidak akan menganggu ketertiban dan keamanan serta tidak membahayakan kepentingan negara dan masyarakat. Penilaian ini dilakukan oleh Ditjen Imigrasi Kemenkumham berkoordinasi dengan instansi terkait (Nina Juwitasari, $2016: 15$ ). 
Tidak hanya persyaratan penggunaan TKA yang wajib berbahasa Indonesia di dalam ketentuan Permenaker yang di hapuskan, tetapi mengenai penghapusan mengenai rasio jumlah TKA dengan Tenaga Kerja Lokal. Hal ini sebelumnya pada pasal 3 Permenaker Nomor 16 Tahun 2015 masih mencantumkan satu orang TKA menyerap 10 tenaga kerja lokal, kemudian adanya perubahan menjadi Permenaker Nomor 35 Tahun 2015 yang salah satunya Pasal 3 di hilangkan.

Menteri Ketenagakerjaan melalui keputusan menteri membatasi jabatan-jabatan yang dapat diduduki oleh Tenaga kerja asing pada beberapa industri. Tenaga kerja asing tidak boleh menduduki jabatan kerja yang dilarang. Jabatan kerja yang dilarang telah diatur dalam Keputusan Menteri Tenaga Kerja dan Transmigrasi Republik Indonesia Nomor 40 Tahun 2012 Tentang Jabatan-Jabatan Tertentu yang Dilarang Diduduki Tenaga Kerja Asing. Lebih kurang ada 19 jabatan kerja yang dilarang untuk tenaga kerja asing, beberapa diantaranya adalah menjadi direktur personalia, manejer hubungan industrial, dan manajer personalia. Jabatan-jabatan tersebut mengatur perihal pengadaan dan penempatan tenaga kerja, penggajian dan pengupahan, serta kompensasi balas jasa dan jaminan sosial. Selain itu juga tentang sistem kontrol personalia, proses pemutusan hubungan kerja,pendidikan dan pelatihan, serta pengembanagan karier. Jadi, TKA dapat bekerja pada jabatan yang tidak di larang dalam Kepmenaker Nomor 40 Tahun 2012. Tujuan dibuatnya keputusan menteri ini adalah untuk memperjelas batasan penggunaan tenaga kerja asing di Indonesia dan untuk melindungi para tenaga kerja indonesia.

Berbeda, jika dilihat dari hukum keimigrasian dalam pasal 61 Undang-undang Nomor 06 Tahun 2011 tentang Keimigrasian yang menyatakan bahwa, "Pemegang Izin Tinggal terbatas sebagaimana dimaksud dalam Pasal 52 huruf e dan huruff dan pemegang Izin Tinggal Tetap sebagaimana dimaksud dalam Pasal 54 ayat (1) huruf $b$ dan huruf $d$ dapat melakukan pekerjaan dan/atau usaha untuk memenuhi kebutuhan hidup dan/atau keluarganya"dimana yang dimaksud dalam Pasal 52 huruf e dan huruf adalah Izin Tinggal terbatas diberikan kepada: 
e. Orang Asing yang kawin secara sah dengan warga negara Indonesia; atau f. anak dari Orang Asing yang kawin secara sah dengan warga negara Indonesia.

Undang-Undang Keimigrasian, dalam hal ini telah memberikan kesempatan kepada orang asing yang menikah dengan warga Negara Indonesia (WNI) untuk bekerja dan berusaha untuk memenuhi kebutuhan hidup dirinya dan keluarganya. Maka, secara tidak langsung bahwa segala jenis usaha dapat dilakukan oleh orang asing yang nanti nya akan bekerja di Indonesia dan pada akhirnya menjadi tenaga kerja asing di Indonesia. Oleh karenanya maka hal ini bertentangan dengan ketentuan hukum ketenagakerjaan yang membatasi keberadaan TKA di Indonesia termasuk jenis usaha yang dapat mereka jalankan melalui Kepmenaker Nomor 40 Tahun 2012. Dikatakan masih ada conflict of norm antara hukum keimigrasian dengan hukum ketenagakerjaan, dimana hukum keimigrasian cenderung lebih memberikan kelonggaran kepada TKA mengenai tidak ada batasan dalam melakukan pekerjaan atau usaha mengenai perkawinan campuran dengan WNI. Sedangkan hukum ketenagakerjaan lebih memperjelas memberikan batasan-batasan untuk TKA jenis pekerjaan atau usaha apa yang boleh diduduki di Indonesia.

Berdasarkan Permenaker Nomor 35 Tahun 2015 sebagai perubahan dari Permenaker Nomor 16 Tahun 2015 tentang tata cara penggunaan Tenaga Kerja Asing kemungkinan dapat menimbulkan masalah, seperti :

1. Penghapusan Rasio Jumlah TKA Dengan Tenaga Kerja Lokal

Dalam Pasal 3 Permenaker Nomor 16 Tahun 2015 diatur bahwa perusahaan yang mempekerjakan 1 (satu) orang TKA harus dapat menyerap sekurang-kurangnya 10 (sepuluh) orang tenaga kerja lokal pada perusahaan yang sama. Walaupun ada pengecualian atas rasio ini jika TKA tersebut akan dipekerjakan untuk posisi tertentu, untuk pekerjaan yang sifatnya darurat dan mendesak, untuk pekerjaan yang sifatnya sementara, dan atau untuk usaha jasa impresariat. Pasal 3 Permenaker 
Nomor 16 Tahun 2015 ini dihapuskan oleh Permenaker Nomor 35 Tahun 2015. Penghapusan pasal ini artinya menghapuskan aturan mengenai rasio jumlah TKA dengan tenaga kerja lokal.

Penghapusan ketentuan dalam Permenaker diatas dikhawatirkan menghilangkan kesempatan terjadinya alih pengetahuan dan alih teknologi dari TKA ke tenaga kerja lokal. Meskipun dalam Pasal 65 Permenaker Nomor 16 Tahun 2015 disebutkan bahwa perusahaan pemberi gkerja dapat menugaskan TKA untuk melakukan alih teknologi dan keahlian di lembaga pendidikan dan pelatihan, namun bisa jadi hal tersebut tidak dilaksanakan jika tidak diwajibkan ketentuan dalam peraturan perundang-undangan. Bahkan Keputusan Direktorat Jenderal yang mengatur mengenai pendampingan TKA oleh tenaga kerja lokal untuk alih teknologi dan keahlian belum diterbitkan sebagaimana disebutkan dalam Pasal 66A Permenaker Nomor 35 Tahun 2015.

Di sisi yang lain, penghapusan rasio ini memberikan kemudahan bagi perusahaan yang berinvestasi di Indonesia untuk memperkerjakan TKA secara lebih murah karena tidak perlu memperkerjakan lebih banyak tenaga kerja lokal dan tidak adanya kewajiban melakukan pelatihan pada tenaga kerja lokal.

2. Larangan Bagi PMDN Untuk Memperkerjakan TKA Sebagai Komisaris

Dalam Permenaker Nomor 16 Tahun 2015 tidak ada larangan bagi perusahaan PMDN (Penanaman Modal Dalam Negeri) untuk memperkerjakan TKA sebagai Komisaris. Namun dalam Permenaker Nomor 35 Tahun 2015 ditambahkan pasal baru antara Pasal 4 dan Pasal 5, yaitu Pasal 4A. Di Pasal 4A ini diatur bahwa perusahaan yang berbentuk PMDN dilarang memperkerjakan TKA dengan jabatan Komisaris. Larangan ini menambah daftar pekerjaan yang tidak boleh diduduki TKA. Sebelumnya dalam Undang-Undang Nomor 13 Tahun 
2003 tentang Ketenagakerjaan hanya diatur bahwa yang dilarang adalah jabatan yang mengurusi personalia atau sumber daya manusia.

3. Penghapusan Keharusan Memiliki IMTA Bagi TKA Yang Tidak Berdomisili Di Indonesia

Di Pasal 37 Permenaker Nomor 16 Tahun 2015 diatur bahwa perusahaan pemberi kerja bagi TKA wajib mengurus izin IMTA, terlepas dari jabatan apapun yang akan diberikan pada TKA tersebut. Pengecualian kewajiban ini hanya berlaku bagi pemberi kerja yang berupa perwakilan negara asing yang mempekerjakan TKA sebagai pegawai diplomatik dan konsuler. Permenaker Nomor 35 Tahun 2015 menambahkan pengecualian kewajiban memiliki IMTA ini bagi perusahaan pemberi kerja yang memperkerjakan TKA sebagai anggota Direksi, anggota Dewan Komisaris atau anggota Pembina, anggota Pengurus, dan anggota Pengawas yang berdomisili di luar negeri. Sementara bagi TKA yang berdomisili di Indonesia tetap wajib untuk memiliki IMTA.

Penambahan pengecualian ini menimbulkan pertanyaan mengenai izin yang harus dikantongi jika TKA yang berdomisili di luar negeri tersebut kemudian datang ke Indonesia untuk urusan pekerjaan yang sementara seperti keperluan rapat, melakukan pekerjaan lain yang dalam waktu singkat. Di satu sisi penghapusan kewajiban mengurus izin IMTA ini membantu mengurangi anggaran dan waktu yang harus disiapkan perusahaan dalam mengurus izin bagi TKA yang akan diperkerjakannya, kecuali bagi perusahaan yang telah mengajukan permohonan IMTA pada periode Oktober sebelum terbitnya Permenaker Nomor 35 Tahun 2015. Tapi di sisi lain perbedaan perlakuan terhadap TKA berdasarkan domisili ini juga berpotensi mengurangi pendapatan negara dari dana kompensasi penggunaan tenaga kerja asing. 


\section{Simpulan}

Politik Hukum Keimigrasian harus berdasarkan kebijakan selektif (Selective Policy) sehingga dapat memberikan manfaat bagi perekonomian Indonesia. Masih adanya conflict of norm antara peraturan keimigrasian dengan peraturan ketenagakerjaan. Oleh karena itu terjadi disharmonisasi antara peraturan dalam hukum keimigrasian dengan peraturan hukum ketenagakerjaan. Peraturan hukum mengenai penggunaan tenaga kerja asing di Indonesia lebih condong memberikan kemudahan bagi tenaga kerja asing tersebut. Karena tujuan penggunaan tenaga kerja asing sebagai alih ilmu pengetahuan dan teknologi dan proses pembangunan nasional dan meningkatkan investasi.

\section{E. Saran}

Sebaiknya pemerintah dengan kementerian ketenagakerjaan melakukan perubahan berkaitan dengan peraturan penggunaan tenaga kerja asing di Indonesia dan tentunya berdasarkan dengan tujuan Negara dalam penggunaan tenaga kerja asing dengan disesuaikan kebijakan selektif (selective policy), agar tidak terjadi disharmonisasi antara peraturan dalam hukum keimigrasian dengan peraturan hukum ketenagakerjaan.

\section{F. Daftar Pustaka}

C.Sumarprihatiningrum. 2006. Penggunaan Tenaga Kerja Asing di Indonesia. Jakarta : HIPSMI.

Hendra Karianga. 2011. Partisipasi Masyarakat Dalam Pengelolaan Keuangan Daerah Perspektif Hukum dan Demokrasi. Bandung: PT Alumni.

H. R. Abdussalam. 2008. Hukum Ketenagakerjaan. Jakarta: Restu Agung.

I Wayan Gde Wiryawan. 2013. "Perlindungan Hak Konstitusional Pekerja Dalam Sistem Hukum Ketenagakerjaan di Indonesia.”Majalah Ilmu Hukum Kertha Wicaksana.Vol. 19 Nomor 2. 
Nina Juwitasari. 2016. "Implikasi yuridis keberadaan tenaga kerja asing sebagai tenaga kerja di Indonesia"Journal Diponegoro Law.Vol5 Nomor 2.

Peter Mahmud Marzuki. 2014. Penelitian Hukum. Jakarta: Prenadamedia Group.

Susi Dwi Harijanti. 2007. Politik Hukum Kewarganegaraan Indonesia. Laporan Akhir Penelitian, Bandung: Fakultas Hukum Unpad.

Tony Mirwanto. 2016. "Sistem Hukum Pengawasan Tenaga Kerja Asing Terhadap Penyalahgunaan Izin Tinggal Kunjungan Untuk Bekerja Pada Perusahaan Penanaman Modal Asing Di Indonesia”. Lex et Societatis, Vol. IV/No. 3.

Ujang Charda S. 2014. "Reformasi Politik Hukum Ketenagakerjaan Dalam Kebijakan Pemerintah Indonesia" Jurnal Wawasan Hukum, Vol. 31 No 2.

Warhan Wirasto Suhaidi. 2016. "Pelaksanaan Pengawasan Warga Negara Asing di Wilayah kerja Kantor Imigrasi Kelas II Belawan Berdasarkan UU NO.6 Tahun 2011 tentang Keimigrasian." USU Law Journal. Vol.4.No.1. 